\title{
Letter to the Editor: Electric Vehicle Demand Model for Load Flow Studies
}

\author{
Garcia-Valle, Rodrigo; Vlachogiannis, loannis (John)
}

Published in:

Electric Power Components \& Systems

Link to article, DOI:

$10.1080 / 15325000802599411$

Publication date:

2009

Document Version

Publisher's PDF, also known as Version of record

Link back to DTU Orbit

Citation (APA):

Garcia-Valle, R., \& Vlachogiannis, I. (2009). Letter to the Editor: Electric Vehicle Demand Model for Load Flow Studies. Electric Power Components \& Systems, 37(5), 577-582. https://doi.org/10.1080/15325000802599411

\section{General rights}

Copyright and moral rights for the publications made accessible in the public portal are retained by the authors and/or other copyright owners and it is a condition of accessing publications that users recognise and abide by the legal requirements associated with these rights.

- Users may download and print one copy of any publication from the public portal for the purpose of private study or research.

- You may not further distribute the material or use it for any profit-making activity or commercial gain

- You may freely distribute the URL identifying the publication in the public portal

If you believe that this document breaches copyright please contact us providing details, and we will remove access to the work immediately and investigate your claim 
This article was downloaded by: [DEFF]

On: 16 September 2009

Access details: Access Details: [subscription number 910491762]

Publisher Taylor \& Francis

Informa Ltd Registered in England and Wales Registered Number: 1072954 Registered office: Mortimer House, 37-41 Mortimer Street, London W1T 3JH, UK

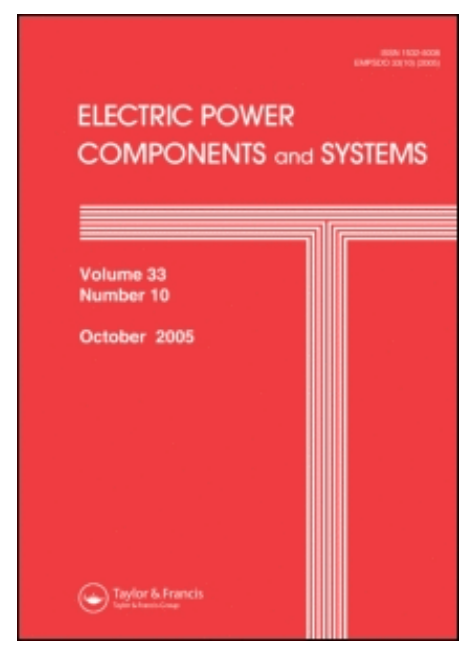

Electric Power Components and Systems

Publication details, including instructions for authors and subscription information: http://www.informaworld.com/smpp/title content=t713399721

\section{Letter to the Editor: Electric Vehicle Demand Model for Load Flow Studies}

Rodrigo Garcia-Valle a; John G. Vlachogiannis ${ }^{a}$

a Department Electrical Engineering, Technical University of Denmark, Kgs., Lyngby, Denmark

Online Publication Date: 01 May 2009

To cite this Article Garcia-Valle, Rodrigo and Vlachogiannis, John G.(2009)'Letter to the Editor: Electric Vehicle Demand Model for Load Flow Studies',Electric Power Components and Systems,37:5,577 - 582

To link to this Article: DOI: $10.1080 / 15325000802599411$

URL: http://dx.doi.org/10.1080/15325000802599411

\section{PLEASE SCROLL DOWN FOR ARTICLE}

Full terms and conditions of use: http://www.informaworld.com/terms-and-conditions-of-access.pdf

This article may be used for research, teaching and private study purposes. Any substantial or systematic reproduction, re-distribution, re-selling, loan or sub-licensing, systematic supply or distribution in any form to anyone is expressly forbidden.

The publisher does not give any warranty express or implied or make any representation that the contents will be complete or accurate or up to date. The accuracy of any instructions, formulae and drug doses should be independently verified with primary sources. The publisher shall not be liable for any loss, actions, claims, proceedings, demand or costs or damages whatsoever or howsoever caused arising directly or indirectly in connection with or arising out of the use of this material. 
Electric Power Components and Systems, 37:577-582, 2009

Copyright (C) Taylor \& Francis Group, LLC

ISSN: $1532-5008$ print/1532-5016 online

DOI: $10.1080 / 15325000802599411$

\title{
Letter to the Editor: Electric Vehicle Demand Model for Load Flow Studies
}

\author{
RODRIGO GARCIA-VALLE ${ }^{1}$ and \\ JOHN G. VLACHOGIANNIS ${ }^{1}$ \\ ${ }^{1}$ Department Electrical Engineering, Technical University of Denmark, \\ Kgs. Lyngby, Denmark
}

\begin{abstract}
This article introduces a specific and simple model for electric vehicles suitable for load flow studies. The electric vehicles demand system is modeled as a $P Q$ bus with stochastic characteristics based on the concept of the queuing theory. All appropriate variables of stochastic $P Q$ buses are given with closed formulas as a function of charging time. A specific manufacturer model of electric vehicles is used as study case.
\end{abstract}

Keywords electric vehicle demand, load flow analysis, steady state

\section{Introduction}

With the introduction of electric vehicles (EVs) into the transport system, the energy sector (mainly the electric power system) will suffer a dramatic change due to this important and expected issue. Therefore, there is a need to develop new models to facilitate the operation and optimal control of the new structure of the power systems.

In the state-of-the-art published material related to EV integration to the electric networks [1-6], there is no model available that incorporates these elements for load flow studies. This article covers this void by introducing a specific and simple model for EVs suitable for load flow studies.

The proposed model considers EV demand systems as $P Q$ buses with stochastic characteristics. The development of the model is based on the queuing theory [7]. The presented formulas for stochastic real and reactive power demand $(P, Q)$ are developed as a function of the charging time (time to be plugged into the power network). The Tesla Roadsters EV model [8] is adopted as a case study; its technical characteristics are considered, and related results are presented.

\section{EV Model for Load Flow Studies}

From the open literature, it is well known that all battery systems in EVs are chemical storage devices, and their charge/discharge modus operandi is the chemical process

Received 5 August 2008; accepted 30 August 2008.

Address correspondence to Dr. John G. Vlachogiannis, Department Electrical Engineering, Technical University of Denmark, Elektrovej Building 326, Room 122, 2800 Kgs. Lyngby, Denmark. E-mail: vlachogiannis@yahoo.com 
[1-6, 8]; therefore, they are exponential functions over time. In this study, the instantaneous charging status of the battery systems of Tesla Roadsters EV [8] is simulated by the following exponential formula:

$$
P_{E V}(t)=P_{E V, \max } \cdot\left(1-e^{-\alpha t / t_{\max }}\right)+P_{E V, 0},
$$

where the current status of the battery system in $\mathrm{kW}$ is simulated by $P_{E V, 0}$, the maximum power capacity for the Tesla Roadster EV is $P_{E V, \max }=189 \mathrm{~kW}$, the maximum charging time is $t_{\max }=3.5 \mathrm{hr}[8]$.

The constant parameter is calculated at the value of $\alpha=6.9077$, assuming that a fully discharged battery system of the Tesla Roadster EV $\left(P_{E V, 0}=0 \mathrm{~kW}\right)$ absorbs $90 \%$ of maximum power capacity $P_{E V, \max }$ in approximately one-third of the maximum charging time $t_{\max } / 3=70 \min [8]$.

Figure 1 shows the charge process of the battery systems of a Tesla Roadster EV for three different initial active power status: $P_{E V, 0}=0 \mathrm{~kW}, P_{E V, 0}=50 \mathrm{~kW}$, and $P_{E V, 0}=100 \mathrm{~kW}$. From these curves, it is observed that the three battery systems need approximately $3.5,0.6737$, and $0.3225 \mathrm{hr}$, respectively, to be fully charged. Obviously, the time to be fully charged is related to its initial active power status. It is assumed that each plug-in EV needs $t_{c}$ hours to be fully charged. Using Eq. (1), it is obtained that

$$
P_{E V, 0}=P_{E V, \max } \cdot e^{-\alpha t_{c} / t_{\max }} .
$$

Equation (2) can be verified with the obtained values of the full charging time for the three different initial active power statuses in Figure 1. Then, the active power of each fully charged $\mathrm{EV}$ is given by

$$
P_{E V, d e m}=P_{E V, \max }-P_{E V, 0} .
$$

From Eqs. (2) and (3), the active power demand of each Tesla Roadster EV is given by

$$
P_{E V, \text { dem }}=P_{E V, \max } \cdot\left(1-e^{-6.9077 \cdot t_{c} / t_{\max }}\right) .
$$

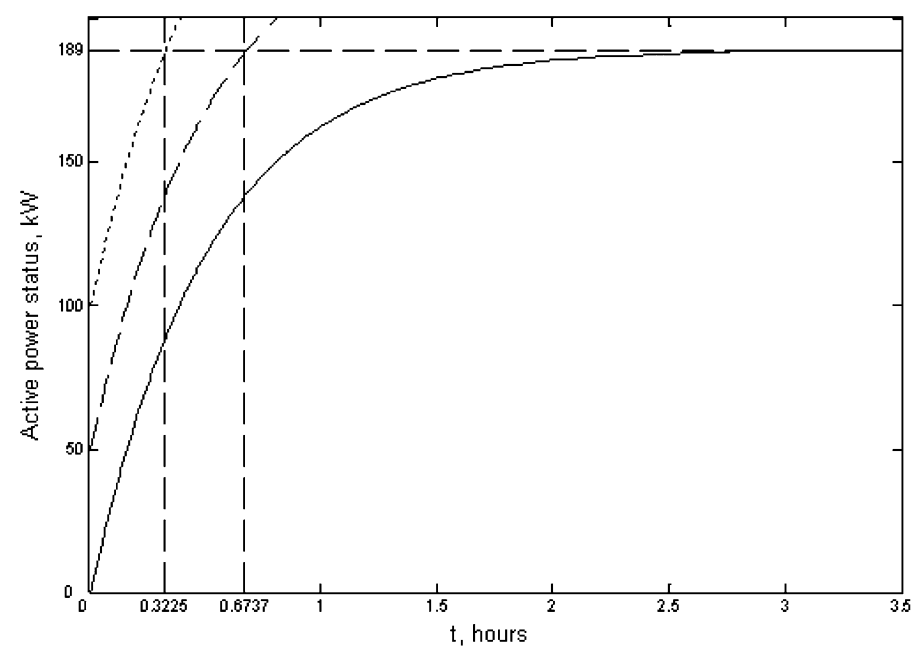

Figure 1. Instantaneous charging status of EV battery systems. 
Furthermore, considering the unity constant power factor of the battery systems $[3,4,8]$, the reactive power demand is given by

$$
Q_{E V, d e m}=0.0 .
$$

\section{EV System Demand Model}

In this article, the power demand model of the EV system at each load bus is developed based on the customer service model originated in the queuing theory [7]. In the $M / M / n_{\max }$ queue, $M$ means the exponential distribution of incoming for charging EVs with a mean of inter-arrival times $1 / \lambda$, mean of service times $1 / \mu$, and $n_{\max }$ maximum parallel charging EVs at each load bus (subsequently called the charging capacity of the load bus). Assuming that there is no time delay in the start of the charge for every EV in the network, it is considered that the mean rate of plugged-in EVs is approximately equal to the mean rate of plugged-out (charged) EVs: $\lambda \approx \mu$. So, the occupation rate of each load bus is [7]

$$
\rho=\frac{\lambda}{\mu \cdot n_{\max }} \approx \frac{1}{n_{\max }} .
$$

Let $p(n)$ denote the probability that there is an $n$-EV system under the charging process at each load bus. In accordance to the $M / M / n_{\max }$ queue theory and the above assumption, the probability $p(n)$ is given by [7]

$$
p(n) \approx \frac{1 / n !}{\sum_{i=0}^{n_{\max }-1} \frac{1}{i !}+\frac{1}{\left(1-\frac{1}{n_{\max }}\right) \cdot n_{\max } !},}
$$

where $n=0,1,2, \ldots, n_{\max }$.

During the off-line load flow process, uniformly distributed random numbers are used in order to calculate the value of charging EVs $(n)$ at each load bus following the process.

For each load bus, generate a random number $r[0,1]$ and set as $n$ the lowest value in the set of values $\left[0,1,2, \ldots, n_{\max }\right]$, which satisfies the inequality

$$
r[0,1]>p(n) .
$$

The full charging time (the service time in the point-of-view of the queuing theory) of each EV is $\left(t_{c}\right)$ follows the exponential possibility distribution with mean of $1 /\left(\mu \cdot n_{\max }\right)$. The density function of this distribution is given by

$$
f\left(t_{c}\right)=\mu \cdot n_{\max } \cdot e^{-\mu \cdot n_{\max } \cdot t_{c}} .
$$

During the off-line load flow process, uniformly distributed random numbers $r(0,1]$ are used for simulating the charging time of each $i \mathrm{EV}\left(t_{c}\right)$ at each load bus as follows [9]

$$
t_{c i}=\left\{\begin{array}{ll}
t_{\max }, & \text { if } r(0,1]<\mu \cdot n_{\max } \cdot e^{-\mu \cdot n_{\max } \cdot t_{\max }} \\
-\frac{1}{\mu \cdot n_{\max }} \cdot \ln \left(\frac{r(0,1]}{\mu \cdot n_{\max }}\right), & \text { if } r(0,1] \geq \mu \cdot n_{\max } \cdot e^{-\mu \cdot n_{\max } \cdot t_{\max }}
\end{array} .\right.
$$




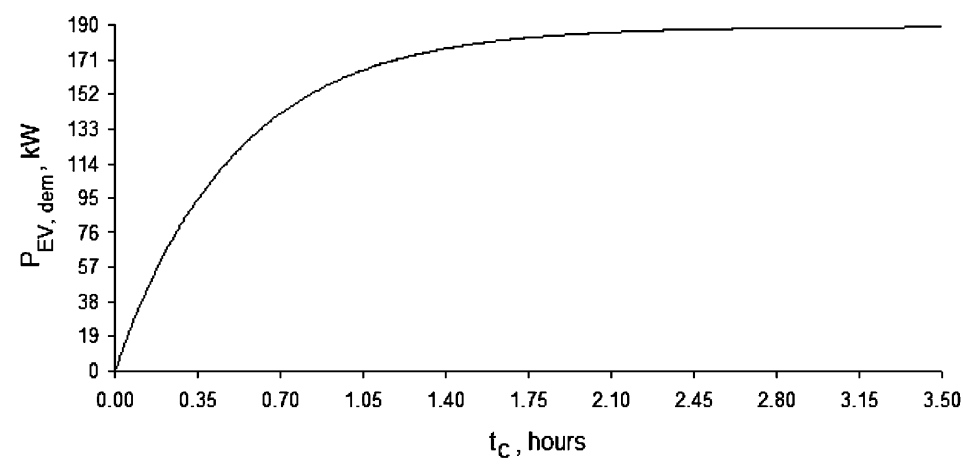

Figure 2. Active power demand of a Tesla Roadster EV to be fully charged.

Conclusively, a system of $n$ Tesla Roadster EVs demands active power form the network given by the following stochastic formula:

$$
P_{D}=P_{E V, \max } \cdot\left(n-e^{-6.9077 \cdot t_{c 1} / t_{\max }}-e^{-6.9077 \cdot t_{c 2} / t_{\max }}-\cdots-e^{-6.9077 \cdot t_{c n} / t_{\max }}\right) .
$$

For remanding purposes, a fully discharged battery system of a Tesla Roadster EV needs approximately $t_{\max }=3.5 \mathrm{hr}$ in order to achieve the $90 \%$ of maximum power capacity $P_{E V, \text { max }}=189 \mathrm{~kW}$. The number of charging Tesla Roadster EV $(n)$ at each load bus, and the full charging time of each of them $\left(t_{c i}\right)$ are calculated using Eqs. (7), (8), and (10), respectively. The charging capacity of each load bus $\left(n_{\max }\right)$ and the mean rate of charging the EVs $(\mu)$ at each load bus would be derived from measurements on a real system. Since there are none at the moment, in this article they are given as constant parameters.

\section{Results}

Figure 2 shows the real power demand $(\mathrm{kW})$ of the Tesla Roadster EV [8] as a function of full charging time $t_{c}$, varying in the range of $0-3.5 \mathrm{hr}$. This study also represents the relation between the full charging time $t_{c}$ and the initial status of the battery systems in Figure 3. Figures 2 and 3 are confirmed by similar experimental plots that appeared in [4] and [6].

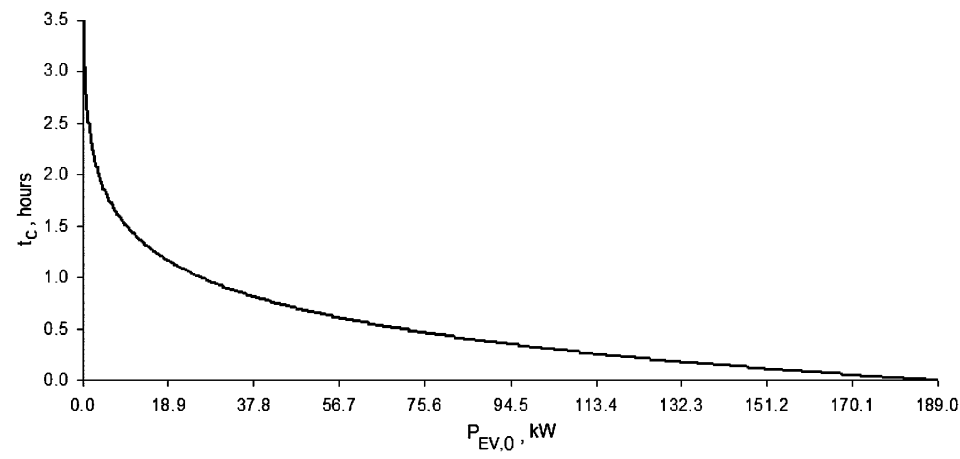

Figure 3. Time required of the battery to be fully charged over its initial status. 


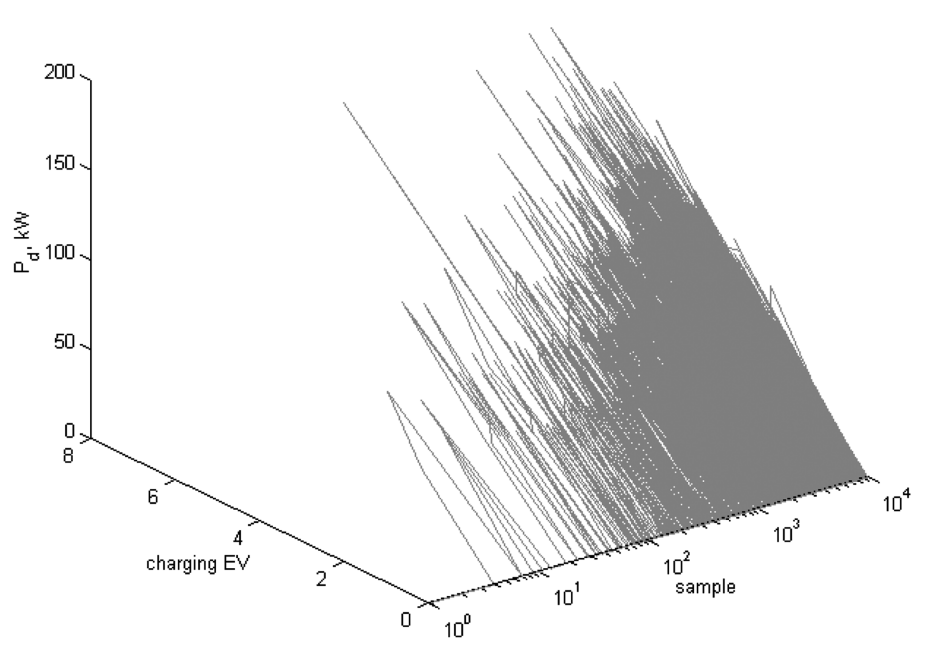

Figure 4. Stochastic real power demand of an $n$-EV system $\left(10^{4}\right.$ samples $)$.

Considering the charging capacity of a load bus $\left(n_{\max }=10\right)$ and mean rate of a charging EVs $(\mu=8)$ at the same load bus, the stochastic real power demand of an $n$-EV system is given in Figure 4. The real power demand (Eq. (11)) is calculated, generating $10^{4}$ samples of $(n+1)$-tuples $\left(n, t_{c 1}, t_{c 2}, \ldots, t_{c n}\right)$. From Figure 5 , the basic load of this small test case study $\left(n_{\max }=10, \mu=8\right)$ is approximately calculated at $64 \mathrm{~kW}$. Based on this study, and for further assessments, the basic load demand of larger $n$-EV systems and their impact on the energy market capacity will be evaluated.

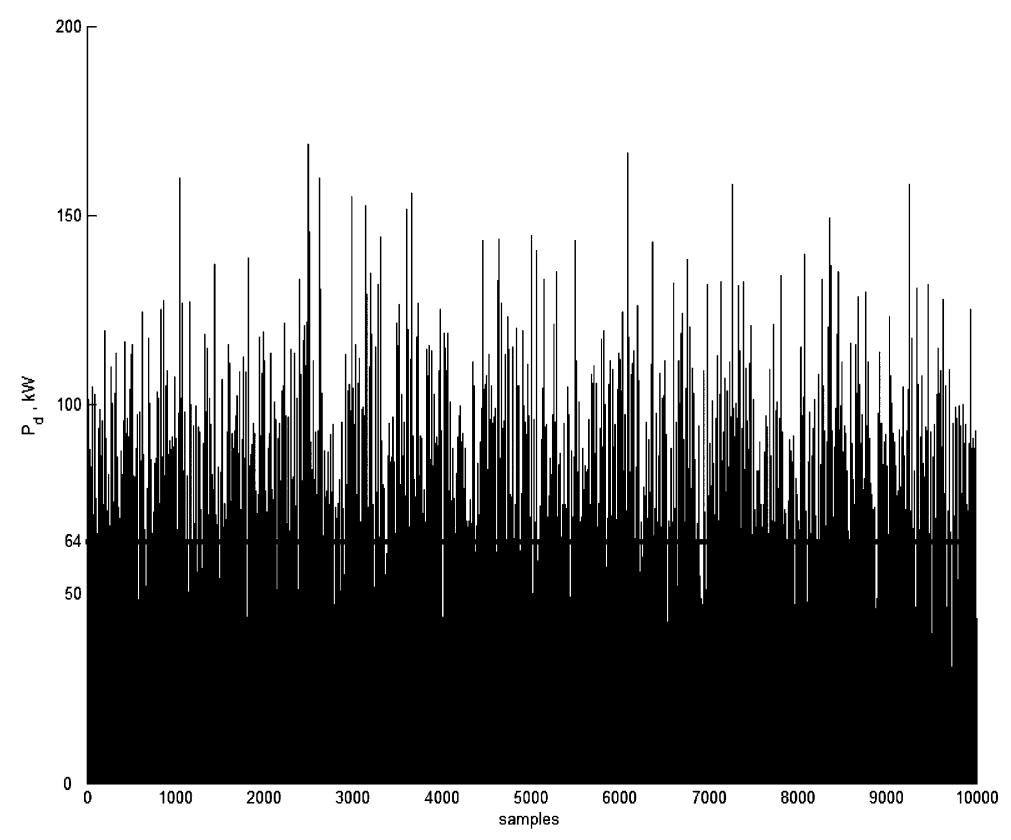

Figure 5. Basic load of $n$-EV system $\left(10^{4}\right.$ samples). 


\section{Conclusions}

In this article, a simple model for an EV demand system suitable for load flow studies is introduced. The developed model considered the EV demand systems as $P Q$ buses with stochastic characteristics. The proposed demand system is developed as inspired by the queuing theory. Closed formulas for the real and reactive power of the EV demand system are developed as a function of the charging time. The proposed model is confirmed using the Tesla Roadster EV as a case study.

\section{References}

1. Lund, H., and Kempton, W., "Integration of renewable energy into the transport and electricity sectors through V2G," Energy Policy, Vol. 36, pp. 3578-3587, September 2008.

2. Zoroofi, S., Modeling and Simulation of Vehicular Power Systems, M.Sc. Thesis, Chalmers University of Technology, Göteborg, Sweden, 2008.

3. Barbir, F., Molter, T., and Dalton, L., "Regenerative fuel cells for energy storage: Efficiency and weight trade-offs," IEEE A\&E Syst. Mag., Vol. 20, pp. 35-40, March 2005.

4. Jiang, Z., and Dougal, R. A., "Control design and testing of a novel fuel-cell-powered batterycharging station," Proc. 18th Ann. IEEE Appl. Power Electron. Conf. Exp. (APEC 03), Vol. 2, pp. 1127-1133, 2003.

5. Chan, C. C., "The state of the art of electric and hybrid vehicles," Proc. IEEE, Vol. 90, No. 2, pp. 247-275, 2002.

6. Lee, W., Choi, D., and Sunwoo, M., "Modelling and simulation of vehicle electric power system,” J. Power Sources, Vol. 109, pp. 58-66, 2002.

7. Adan, I., and Resing, J., "Queueing theory," available at: http://www.win.tue.nl/ iadan/queueing. pdf, Department of Mathematics and Computing Science, Eindhoven University of Technology, The Netherlands, 2002.

8. "Tesla Roadster EV," available at: http://www.teslamotors.com.

9. Trivedi, K. S., Probability and Statistics with Reliability, Queuing, and Computer Science Applications, 2nd ed., Hoboken, NJ: Wiley \& Sons, 2001. 